\title{
Righting The Subalterns? NeEl MuKHERJEe's THE LIVES OF OTHERS AND THE NAXALITE MOVEMENT
}

\author{
CARLOTTA MARIA BERETTA \\ Università di Bologna, Italy \\ carlotta.beretta2@unibo.it
}

Received: 31-10-2018

Accepted: 10-01-2019

\begin{abstract}
Neel Mukherjee's second novel The Lives of Others deals with the story of a family during one of the most controversial chapters in the recent history of West Bengal, namely the Naxalite movement and its subsequent repression by the State. The novel examines the reasons why so many young middle-class students decided to join the movement, and the actual impact of their activism. In doing so, it questions Bengali society and the relationship between different social classes. Above all, The Lives of Others is a bourgeois novel which explores and criticizes the contradiction and conflicts within the Bengali middle class. Although the subalterns, especially the peasants, played a significant role in the Naxalite movement, they are at the margins of the novel and are rarely given a voice. This paper will read The Lives of Others as an allegory of Bengali society. Such a reading will primarily look at the dialectics of society in the novel, thus providing a context in which to discuss class conflicts and the paradox represented by a bourgeois novel about a subaltern revolution. The comparison with a well-known novel of the time, Mahasweta Devi's Mother of 1084, will also be fundamental for the discussion.
\end{abstract}

KEYWORDS: Neel Mukherjee, Naxalite movement, West Bengal, Mahasweta Devi, postcolonial, Communist Party of India

RESUMEN: ¿Re-componiendo a los subalternos? The Lives of Others, de Neel Mukherjee, y el movimiento naxalita

La segunda novela de Neel Mukherjee, The Lives of Others, trata la historia de una familia durante uno de los capítulos más polémicos de la historia reciente de Bengala: el movimiento naxalita y su posterior represión por parte del Estado. La novela examina las razones por las que tantas y tantos jóvenes estudiantes de clase media decidieron unirse al movimiento, así como el impacto real de su activismo, cuestionando la sociedad bengalí y la relación entre las diferentes clases sociales. Sin embargo, The Lives of Others es más bien una novela burguesa clásica que no una novela centrada en dar voz a los subalternos. De hecho, el autor utiliza el movimiento naxalita principalmente para criticar la clase media hacia la cual éste fue dirigido. Este artículo propone una lectura de The Lives of Others como una alegoría de la sociedad bengalí. Dicha lectura se centrará principalmente en la dialéctica de la sociedad en la novela, proporcionando así un contexto en el que tratar los conflictos de clase y la paradoja que representa una novela burguesa sobre una revolución subalterna. Igualmente, se comparará la novela con otra conocida de la época, Mother of 1084, de Mahasweta Devi, también fundamental para la discusión.

Palabras Clave: Neel Mukherjee; movimiento Naxalita; Bengal Occidental; Mahasweta Devi; poscolonial: Partido comunista de India 


\section{Introduction}

The Lives of Others is the second novel by Neel Mukherjee, published in 2014. Unlike his first novel Past Continuous, which deals with Indian diaspora in the United Kingdom, The Lives of Others is set in Calcutta and in the countryside of West Bengal. The novel tells the story of a family during one of the most controversial chapters in the recent history of West Bengal, namely the Naxalite movement and its subsequent repression by the State (1967-1973).

The revolutionary movement came out of the turbulent political climate of the $1960 \mathrm{~s}$. The decade witnessed a shift in power in West Bengal from the Congress Party to a left-wing coalition (first named United-Front, then Left-Front), which subsequently governed until 2011. Parallel to this change in state power, some members of the Communist Party of India disagreed with the prevailing party line and decided to attempt an armed revolution. The uprising began in 1967 in the rural village of Naxalbari. Soon it came to involve other rural areas, the city of Calcutta, and ultimately it spread across India. Following the example of Maoist China, the revolutionaries aimed at a revolt of the peasantry against the status-quo. However, their strategies went beyond that of pure armed struggle and, in time, included political assassinations and terrorism. The movement was heavily repressed by the State which, in turn, used targeted killings and mass incarcerations. By 1973, the Naxalite movement was militarily defeated by the Indian government. Today, there are still some zones under Naxalite influence, mainly jungle and rural territories in Central India. However, the Indian army heavily guards these districts and the Naxalites do not hold any power in urban areas. Also, the leadership of the movement has profoundly changed from urban middle-class intellectuals to tribal young men and women (Singh 2016: 97).

Due to its varied composition which, at the beginning, involved communist cadres, middleclass university students from Calcutta, and peasants from the rural areas, the issue of the relationship between different social classes is central to the history of the Naxalite movement. Before the uprising in Naxalbari, there had been several instances of peasant revolt in rural areas, even in colonial times. In Elementary Aspects of Peasant Insurgency (1983), Ranajit Guha describes the history of agrarian disturbances in the Subcontinent as "endemic" and "as old as colonialism itself" (1). Therefore, the novelty of the Naxalbari uprising rests not on the decision of the peasants to rise against the status quo, but on the fact that it was an attempt to bring together for the first time the peasants' struggle with that of the unemployed urban youth and the petty bourgeoisie. In Calcutta, the movement was mainly made of students, and did not succeed in 
involving the working classes (industrial proletariat). In the rural areas, communist cadres and students from the city collaborated with peasants. Therefore, the subaltern classes that took part in the movement were mostly rural workers and tribal people, largely excluded from hegemonic power structures and geographically separated from the world of the city. Given this class division among the Naxalites, there was a tension between what mattered to the people in the countryside (food shortage, capitalist farming, labour conditions), and the issues that mobilised the urban population (unemployment, living conditions, crisis of the academic system). Gradually, the connection between classes failed and the movement, which started as an agrarian revolt, drifted towards urban terrorism (Roy 1975: 242). According to Rabindra Ray (1988), the shift towards terrorism and the annihilation of the class enemy had its causes in the political ideology of the movement, which verged on nihilism. The action of the peasants was brought about by years of oppression. Instead, the urban component was mostly driven by frustration and anger towards the status quo. This degenerated into a destructive and nihilistic venture (Banerjee 1980).

This tension between classes is at the core of Neel Mukherjee's novel. The Lives of Others opens with an impactful murder-suicide scene that gives the full proportion of the toil of rural workers. Violence permeates the lives of the peasants who experience exploitation, poverty, and various other forms of social injustice. The novel clearly connects this situation with the violent response of the Naxalite revolution. In addition to the struggle in the countryside, The Lives of Others represents various members of the urban lower classes, such as domestic and factory workers, and describes their conflicts with the ruling classes. Therefore, in the novel, the category of the "subaltern" comes to include "all that is not bourgeois (in a European sense) in Indian capitalism and modernity" (Chakrabarty 2000: 11), and not just the peasant in a sociological sense. Consequently, this paper, too, will adopt this extended usage of the term.

Despite all this, The Lives of Others is more a classic bourgeois novel than an attempt to give voice to the subaltern. Indeed, reviewers have likened it to a Victorian novel (Desai 2015) or to Thomas Mann's Buddenbrooks (Sampietro 2016). Buddenbrooks (1901) offers a compelling portrait of the decadent German bourgeoisie; likewise, Mukherjee's fiction uses the Naxalite revolution mostly to critique the middle-class against which it took place. The space given to the lower classes' viewpoint and actions is very limited.

Taking my cue from Fredric Jameson's The Political Unconscious (1981), this paper will read The Lives of Others as an allegory of Bengali society, with the aim of unearthing and discussing the social conflicts which permeated it during the 1960s and 1970s. Indeed, for Jameson, 
literature is a socially symbolic act, and the cultural text is "an essentially allegorical model of society as a whole" (1981: 33). Such a reading will primarily look at the dialectics of society in the novel, thus providing a context in which to discuss class conflicts and the paradox represented by a bourgeois novel about a subaltern revolution. The comparison with a well-known novel, written right after the Naxalite uprising, Mahasweta Devi's Mother of 1084 (1974), will also be fundamental for the discussion. Though undoubtedly a source of inspiration for Mukherjee's novel, Devi's work provides quite a different perspective on Bengali society.

\section{A Bengali Middle-Class Family}

The Lives of Others presents a contrapuntal structure in which two narrative strands are continuously juxtaposed. On the one hand, it tells the story of the middle-class Ghosh family whose members live at the 22/6 of Basanta Bose Road in Calcutta. The large four-storey house accommodates the patriarch Prafullanath and his wife Charubala, together with their five children and their families. The family owns a paper manufacturing company, with several paper mills all over Bengal. The business was once prosperous, but now faces a time of crisis, due to bad management, union unrest, and the economic depression that affected West Bengal in the 1960s and 1970s. On the other hand, the novel gives an account of the Naxalite struggle through the eyes of the oldest grandchild of the family, Supratik, who has left Calcutta to join the movement in the rural areas of West Bengal. Through the letters he sends to his aunt Purba, Supratik explains his political journey and the difficulties and challenges of taking part to the rural unrest. The choice of a contrapuntal structure emphasises from the beginning a dialectic juxtaposition, a conflict, between the Ghosh family and Supratik, between the middle-class and the university-educated youth.

The first narrative strand focuses on the Bengali bourgeoisie and its relationship with the rest of society. The house on Basanta Bose Road can be seen as an allegory of the Bengali social milieu, due to its rigid social structure and its continuous contrasts and divisions. Its members quarrel and fight among themselves all the time over money, status and privilege; a continuous turbulence that resembles the 1960s and 1970s political climate. In addition, the space of the house is organized in a rigid hierarchical order, and there are various forms of discrimination between different family members. The patriarch Prafullanath with his wife, Charubala, dominate the house from the top floor, like a couple of gods (Desai 2015). The rules they impose on the space of the house provide a form of spatial organisation, but do not guarantee harmony and well-being among family members. Indeed, the inhabitants of the house are assigned their rooms according to age, 
power, and status with respect to other family members, in a descending order. Thus, on the top floor, together with the patriarchal couple, live Adinath, the oldest son and heir of the family business, his wife and children. On the second floor, lives Chhaya, the spinster sister. On the first floor live Priyonath, the second born, and Bholanath, the third child, together with their families. On the ground floor there are rooms for the servants and for Purba, the widow of the youngest son, and her children, "hidden away... as if they were servants and not what they really are, true family" (Mukherjee 2014: 17).

Every member of the Ghosh household is in charge of part of the family business or of the house chores. Adinath and Priyo manage the paper mill company together with their father. Bhola, regarded as too inept, owns a failing publishing house. Among the women, Sandhya, Adinath's wife, manages the house. After her illness, Purnima, Priyo's wife, will take her place. Purba has to deal with the lesser tasks, like a servant:

Purba, on the one evening she is suffered to come to the grand living room on the first floor and mingle relatively freely, so that everyone else can have the desirably short-lived luxury of playing One Big Happy Family, is, in reality on menial duty, as always; she stands in a corner and hands out plates of sweets, clears away empty cups and saucers, refills glasses with water, even though there is a small fleet of servants to do these chores. (Mukherjee 2014: 59)

A widow, and also from a lower-class upbringing, Purba is rejected by the rest of the family. She has to complete the same chores as a common servant; she cannot eat with the rest of the family (nor eat the same food, for that matter); she is forbidden to use dish-soap to clean her plates; her children do not have the same educational opportunities that their wealthier cousins have.

While inequalities and discrimination are particularly striking in Purba's case, they actually concern the entire Ghosh household, both from an affective and an economic point of view:

Not all family bonds are equal. The lie so assiduously propagated by mothers... is disbelieved by everyone, yet it is quite astonishing what pervasive currency it has in the outward show of lives. Everyone is hectically denying the existence of favourites, of special affections and allegiances and alliances within a large group of siblings, or between parents and children, while, just under the surface, the empty drama of equality is torqued to its very opposite by the forces of conflicting emotions and affinities. (Mukherjee 2014: 105)

Equality - both emotional and economic - among its members is an unattainable condition in the Ghosh family. On the affective side, Priyo and Chhaya share a strong bond that surpasses even that between Priyo and his wife. Among the children, Prafullanath prefers his last-born, Somnath, a fact 
that causes jealousy, rivalries, and quarrels. On the economic side, both Adinath and Priyo run the paper mills, sharing similar responsibilities, but only Adinath will inherit the business. All other family members are excluded from the company.

In The Lives of Others, the inequalities in the Ghosh's household go together with a general physical and moral decay. Somnath, the fourth child and Purba's deceased husband, is a drunkard and a serial rapist, whom the family tries to protect in every possible way. After Somnath's death, Prafullanath takes to bed and leaves the business to Adinath and Priyo. Adinath is an alcoholic, and his younger son, Suranjan, a drug addict. Priyo and his sister Chhaya are secretly in love. Priyo has peculiar sexual appetites as well. Sandhya, Adinath's wife and Supratik's mother, spends her days in her bedroom and refrains from familial duties after Supratik disappears from the house. In addition, frequent quarrels and disputes about money and status plague the household.

The Ghosh's decay does not stand only for their loss of morality. It reflects also the crisis in their paper mill business. Prafullanath, Adinath and Priyo share the responsibility of running the company, but do not have a common vision and keep making wrong decisions. Moreover, if we take the Ghoshes as an epitome of the entire Bengali middle-class in the late 1960s, their decadence also mirrors the profound social, political, and economic crisis that affects the bourgeoisie in that period.

During the 1960s and 1970s, the economic crisis in West Bengal also meant a loss of political power by the upper middle-class. Rural uprisings, the Food Movement and then the Naxalite movement were a challenge to the status-quo. In politics, the election of a United Front government ended the power of the Congress, which was the expression of the Bengali industrialists. Indeed, historians such as Sumanta Banerjee in In the wake of Naxalbari (1980) and Rabindra Ray in The Naxalites and their ideology (1988) maintain that in that period there was a clear fracture between the industrialists and the rest of society (petty bourgeoisie and lower classes). As unemployment and dissatisfaction rose, many people turned to the United Front or to the Naxalite movement in the hope of changing society. This is particularly true of the case of university students like Supratik, who is increasingly politicized and critical towards his parents' generation, and who ends up in the ranks of the revolutionaries.

In the novel, the social rupture can be clearly seen in the two siege episodes. The first happens when the family house is literally sieged by two maidservants who come to accuse Somnath of rape. Charubala gives the order to brush them away, but they remain in the street 
shouting about Somnath's deeds. Therefore, the family has to close windows and doors and move to the back of the house, so as not to hear their voices:

At last Chhaya spoke, her voice emerging in a croak, 'We should go to the back of the house.' She leaped up and called out, 'Madan-da, Madan-da. Shut all the doors and windows on all the floors right now.' But the damage had been done. The great, roaring world outside - against that, what match were these transient bits of straw? (Mukherjee 2014: 332)

The second siege episode involves the men of the house. As one of the paper mills is shut down by workers on strike, Prafullanath decides to go to the factory in order to confront Dulal, the workers' leader. However, the dialogue fails and Prafullanath and his sons end up trapped in their car, surrounded by a mob of angry workers - a gherao $^{l}$ that ends only because the driver runs over some of them. This terrible episode - much more than the previous siege - highlights the irreparable divisions that characterise the 1960s and 1970s political climate.

In theory, the role of the middle-class should be that of a mediator between the lower and upper classes. At the dawn of the Industrial Revolution, James Mill, in An Essay on Government (1824), argued that the middle-class should guide, advice, and act as a model for the lower classes (Mill 1824: 73). Similarly, Independent India was founded on the leadership of the middle-class, politically represented by the Congress Party. In The Lives of Others, this guiding role is completely lost, as is the dialogue with the masses that leaders such as Gandhi and Nehru continuously cultivated. In the 1920s, for example, Bengali politics witnessed an alliance between the Congress and several revolutionary terrorist groups, which contributed to laying the organisational foundation of the Congress and to the commencement of mass movements (Partha Chatterjee 1990: 27-28).

These two siege episodes also provide a perspective on subaltern agency. In both instances, the subalterns decide and act for themselves, challenging the authority of the middle-class. However, their revolutionary acts are never successful and the subalterns' perspective is always mediated by the middle-class gaze. The same is true for the second narrative strand: in the letters Supratik sends home, we always see the subalterns through his eyes, and never hear their point of view. Also, the subalterns are rarely the protagonists of the struggle: Supratik and his comrades appear to oversee and take part to much of the action.

\section{The Naxalite movement: young middle-class revolutionaries}

\footnotetext{
${ }^{1}$ A gherao is a form of protest in which workers prevent employers from leaving the workplace until certain demands are met.
} 
The second narrative strand takes up Supratik's point of view, which contrasts strikingly with that of his family. Indeed, contrary to the other members of the Ghosh's household, Supratik tries to overcome social boundaries and becomes a communist activist and, later, a Naxalite fighter. He first gets into politics at Presidency College, as a member of the Students' Federation, the student wing of the Communist Party of India (Marxist) ${ }^{2}$. There, Supratik takes part in the Food Movement in the late 1960s and, subsequently, in the gherao of the college principal as well as in other political actions. However, he soon gets the feeling that he is not doing enough and that the real fight is elsewhere. Following the ideas of Charu Mazumdar and of the CPI (Marxist-Leninist), Supratik decides to take the side of the oppressed.

Nevertheless, his choice does not prove to be easy. Through Supratik's first person narration, we see how difficult it is for him to get used to life in the paddy fields and to get rid of his middle-class upbringing:

My palms and fingers were a mad criss-cross of little cuts from the sharp, dry edges of the rice leaves and stalks. Shame rose in me like bile. Hands that revealed instantly that I hadn't done a day's honest work in my life... I wanted to make the cuts worse, deeper, my hands really bloody. It was the only way I would learn how to harvest properly and the only way my hands could stop being the shamefully middle-class hands they were now. 'Change yourself, change the world'. (Mukherjee 2014: 145)

Supratik rejects the bourgeois way of life, and tries to adjust to rural habits. To him, the change, the fight against himself and his middle-class background are the first steps towards the revolution. However, his difficulties point to the unbridgeable gap that exists between the middle-class and the subalterns:

I feel ashamed to admit to feeling the bite of those hardships; really, a middle-class cream-doll, that's what I am. It hurts to acknowledge this. I worried about how swiftly this catalogue of difficulties and woes could descend into an easy horrorism; I have always wanted to avoid that. What use did it serve to emphasise the unbridgeable gap between the lives of these people and people of our kind? It only consoled and comforted the middle classes that their lot was better... It was not awareness they were after, it was the reinforcement of the separation between 'us' and 'them'. (Mukherjee 2014: 241)

\footnotetext{
2 The Communist Party of India (CPI) went through several divisions in the course of the 1960s. Following the SinoIndian border war in 1962, the CPI-M (Marxist) broke with the main party line, the pro-USSR CPI, as its member were Maoist and therefore pro-China. The next division, instead, brought to the fore the conflict between the constitutional line and the revolutionary path. In 1969, the CPI-M-L (Marxist-Leninist) left the CPI-M, in open support of the armed struggle of the Naxalites. The CPI-M-L was lead by Charu Mazumdar.
} 
As much as he tries to change himself and become a subaltern, Supratik cannot help but feel the hardships and acknowledge his difference. He is also aware that it is exactly this "unbridgeable gap" that reinforces the prejudices of the people like his family members. To bridge the difference, Supratik tries to feel and experience "the lives of others":

On some nights, I lie awake, trying to imagine being someone else, someone who has crossed my path that day, say, the man who was selling me fritters at the mela in Munirgram... First, I concentrate to bring into sharp focus every detail of his face and clothes and bearing. When I get that, I move one step further and try to imagine his life in as much detail and minuteness as I can... Sometimes I use a different approach. I concentrate on one probable experience in his life and try to become him and live that experience in every single sensation and feeling. (Mukherjee 2014: 177)

Imagination and empathy seem to Supratik the only ways to truly put himself in relation with the lives of the subalterns, and this, in a sense, becomes a means to mend the distance between the student and subaltern component of the Naxalite movement. However, Supratik's attempt can also be seen as an obliteration or absorption of the subalterns' viewpoint on part of a middle-class man. Indeed, using Supratik's first person narration, The Lives of Others filters the subalterns' perspective through a middle-class one, and does not give them voice. As readers, we experience the subalterns only as objects in the narration of a middle-class subject.

The issue of the relation between the middle-class and the subalterns also is a prime concern of Mahasweta Devi's Mother of 1084, written in 1974, right after the events of the 1960s and early 1970s. There are many similarities that can be traced between Devi's novel and The Lives of Others. In Mother of 1084, Brati, the youngest son of a well-off middle-class family, rejects his middleclass upbringing and the bourgeois value-system, and becomes a Naxalite:

When Brati began to change it was not due only to books or political lectures... Brati felt the anguish of men like Somu, son of poor parents, or those like Laltu, humiliated by fate and life, and other men like them, as keenly as if it was his own, and that had caused him to change. Life itself had forced him to change. He gave up the life he was born to. (Devi 1974: 68)

Contrary to Supratik, Brati's change appears to come about quite effortlessly, and empathy seems more natural to him. Moreover, with respect to The Lives of Others, Mother of 1084 does not focus on class divisions within the Naxalite movement, but on the separation between those who acknowledge the importance of the fight, and those who ignore the toil of the subalterns and go on with their middle-class lives. Devi's novel chooses to recount the events from the perspective of a 
grieving mother who, little by little, understands the reasons why her son joined the Naxalite movement and lost his life.

Compared to other works by Mahasweta Devi, in which she gives voice to the point of view of the subalterns (and especially of the Adivasi people), Mother of 1084 deals with the Naxalite movement mainly from a middle-class perspective. Like Supratik, Sujata and Brati come from a well-off middle-class family. The head of the family, Dibyanath Chatterjee, is a successful businessman and unloving husband who controls the "beautifully organized household" (Devi 1974: 30) in a boss-like manner. Dibyanath and his children hold on to middle-class values of "respectability, comfort and security" (15). These "values" prompt them to erase Brati's death from public record and cast their son and brother into oblivion. Sujata cannot accept this, but also cannot fully connect the behaviour of her family members to bourgeois ideology.

It is only following her son's steps that Sujata comes to question her middle-class world. She visits the mother of Somu, Brati's friend and comrade, killed on the same night. While the two find comfort in sharing the grief for the loss of a son, Sujata slowly comes to realize that their respective social conditions draw a barrier between them. For Somu's family, the death of a son puts a further economic strain on their already precarious lives. Moreover, Somu's mother could never understand the absence of communication between Brati and his family, particularly with his mother. Sujata finds herself caught between class divisions. On the one hand, she can empathise with Somu's mother, however, their economic conditions draw them apart. On the other hand, she cannot accept her middle-class world anymore. Sujata starts to feel a deep detachment from the rest of her family, as if Brati and his comrades were the only ones still alive, and all the others were dead:

It was all like a festering, malignant cancer. The dead pretended to live within relationships that were long dead and thus keep up a masquerade of life... The society that Brati and his comrades had tried to exterminate kept thousands starving in order to nourish and support these vermin. It was a society that gave the dead the right to live, and denied it to the living. (Devi 1974: 115)

As in The Lives of Others, the novel points to the moral and physical decadence of the middle-class, and questions its role in society whilst praising those who tried to change the state of things and better the conditions of the poor.

Mahasweta Devi's Mother of 1084 depicts the Naxalite movement in a fully sympathetic and positive manner. When reflecting upon the failure of the revolution, the novel points the finger 
against the traitors inside the movement, and, above all, against the indifference of the intellectuals and of the politically disengaged masses. To Mahasweta Devi, the personal is political, as Sujata's narrative arch demonstrates. For this reason, it is impossible to avoid social evils and not to take a stand against them. Those who do not take a stand are siding with the perpetrators:

Betrayal. There are all those who talk for the sake of talking, never realizing even that in the process they are betraying us. Why do these poets have to cry their hearts out over Bangladesh in the Seventies and go on churning out poems dripping with sentiment? Betrayal. Why do the round-ups continue? The firings within the prisons? The arrests? Betrayal. (Devi 1974: 78)

Here the novel explicitly condemns the intellectuals who write and speak for the cause of Bangladesh (in the context of the war against Pakistan for independence), but do not spare a word for the Bengali youth who are dying under State repression, or for the terrible conditions of the rural areas. Yet again, for Devi, it is the betrayal and the indifference of the rest of society that lets down the movement and its members.

The Lives of Others shares a similar idea of the divisions and conflicts traversing Bengali society at the time. Nevertheless, the viewpoint on the movement that the novel puts forward is quite different. Once Supratik comes back to Calcutta to take part in urban actions, his vision of the "outside world" collides with that of his family:

'You've blackened our face,' Adinath launches in. 'You've brought down so much shame upon us that we cannot show our face to the outside world any more.'

What does his father know of the 'outside world' that he cannot bring himself to name any longer? It is Supratik who knows about it: he has loped in and out of that demesne with the cautiousness of a preyed-upon animal. And fear? Yes, that too; he knows he is going to be hunted down. There is an inevitability about it that he finds oddly liberating, even euphoric at times. Yes, he knows that outside world. (Mukherjee 2014: 420)

As in Mother of 1084, Adinath, Supratik's father, champions the middle-class values of respectability and order. In Adinath's eyes, the world outside is about what this world makes of you, about reputation and shame. For the young Naxalite, the expression "the world outside" is ambiguous, in that it speaks of the location of every single individual in the world at large: "Does that mean that the world is wherever one is?" (Mukherjee 2014: 240). To Supratik the "real world" is that of the subalterns. In contrast, there is his father's world, that of the Calcutta middle-class which cares only about appearances. 
Towards the end of the novel, Supratik steals some family jewels to finance political activities, and he lets Madan, the cook, take the blame. In other words, he decides to sacrifice one servant, for the sake of others like him. Later, however, the sacrifice begins to feel more like a betrayal:

Did he... did he go down that route because of reasons of class, because a servant stealing is so much more credible, so much more natural, than a member of the family? Was it to make the theft believable to the police that he had framed Madan-da, or was it because it had cost less to betray a servant than one's own kind? (Mukherjee 2014: 478)

Similar to Mother of 1084, the theme of betrayal runs through the concluding part of the novel. However, in The Lives of Others it involves the middle-class members of the movement, and not the middle-class outside the movement. Again, Mukherjee's novel points to the unbridgeable gap between classes. It seems to suggest that it was impossible for the middle-class members of the movement to fully forget where they belonged and shred class solidarity with the bourgeoisie. Another element that the novel highlights is that of sacrifice, of disposing of innocent people for a greater good. Madan's destiny will be a painful one: arrested instead of Supratik, he will lose his job and, once out of jail, he will take his own life. In the second epilogue of The Lives of Others, after Supratik's death, we witness his comrades still in action: they are using a type of bomb that Supratik invented to derail a train. In a dismal turn of events, the bomb is the only legacy that Supratik leaves to the movement. Again, a tool that allows the sacrifice of innocent people in the name of the political struggle. In both cases, the novel appears to question the morality of Supratik's actions, as well as their effectiveness for the actual goal of the liberation of the subalterns. Indeed, the destructiveness that Supratik brings upon himself and upon innocent people (the cook, the people on the train) does not seem to benefit the subalterns in any way. This destructiveness is connected by historians with the shift of the movement towards nihilistic actions and to the failure of the inter-class connection between the urban middle-class students and the peasants.

\section{Conclusion}

Historians identify the nihilistic existential ideology of the Naxalite movement as one of the causes for the failure of the revolution. For example, Sumanta Banerjee connects the revolutionaries' destructiveness to their failure to get support from a larger component of society, as "they... 
prompted a political moral confusion, sometimes verging on nihilism, which threatened liberal values and helped provoke a backlash" (1980: 273). Similarly, Rabindra Ray (1988) links the use of terrorism and political assassinations to a nihilistic ideology, and that, in turn, to the Naxalites' inability to gain the support of the industrial proletariat. With its emphasis on killings, bombings, and the sacrifice of innocent people, Neel Mukherjee's novel seems to agree with these theses.

In addition, The Lives of Others focuses on class divisions both outside and inside the movement: the problem rests not only on the ruptures between the middle-class, the Naxalites, and the rest of society, but also within the movement itself. The gap between the young middle-class activists and the subalterns is evident, and the novel seems to recognize in this division a secondary cause for the failure of the movement. The middle-class Naxalites manage all the political actions, and are unable to fully connect with the subalterns, both in rural and urban areas.

More in general, the subalterns do not appear as the protagonists of the movement - nor of the novel. Although in some instances The Lives of Others gives them agency and voice - namely in the two siege-episodes - the subalterns as subjects are mostly constructed in opposition to the middle-class. Worse still, in the countryside, the peasants are not given a voice and do not appear as fully-fledged political subjects, for the narrative filters their experience through Supratik's. In "Can the subaltern speak?" (1988), Gayatri Spivak describes the construction of the subaltern subject as Other, filtered through the voice of those who speak for her. A similar mechanism is at work in The Lives of Others: the subalterns, the Other(s) are constructed through the viewpoint of the middleclass and, as such, functional as a discourse on the middle-class. In this respect, Mahasweta Devi's approach in Mother of 1084 is radically different in that the subalterns - namely Somu's family emerge in all their difference, not just on an economic but also an emotional level with respect to Sujata and her family.

In The Lives of Others, Neel Mukherjee provides a portrait of a fractured Bengali society, where every component seems unable to communicate with the other. Taking up the point of view of the middle-class, the novel is more a parable on bourgeois values and their decay than a look at the subaltern experience. The dialectical structure upon which it is based puts an emphasis on the many contradictions and juxtapositions which tear apart both the Ghosh's household and Bengali society at large. As Franco Moretti maintains in The Bourgeois (2013), there is no unique cultural trait that distinguishes the bourgeoisie from the rest of society; indeed, its most noticeable characteristics seem to be variety and the coexistence of multiple contradictions and antinomies (5). 
Thus, it is perhaps its emphasis on conflicts and contradictions within the middle-class that makes

The Lives of Others first and foremost a bourgeois novel.

\section{WORKS CITED}

BANERJEE, SUMANTA. (1980). In the Wake of Naxalbari: a History of the Naxalite Movement in India. Calcutta: Subarnarekha.

CHAKRABARTY, DIPESH. (2000). Provincializing Europe. Princeton: Princeton University Press.

CHATTERJEE, PARTA. (1990). "The Political Culture of Calcutta". In: Sukanta Chaudhuri (ed), Calcutta: The Living City, Volume II: The Present and the Future. Delhi: Oxford University Press.

DESAI, ANITA. (2015). "The Real India", The New York Review of Books, 22 ${ }^{\text {nd }}$ October 2015. $<$ https://www.nybooks.com/articles/2015/10/22/real-india/ > Accessed 31/10/2018

DEVI, MAHASWETA. (1974). Mother of 1084 [Hajar Churashir Maa]. Trad. S. Bandopadhyay. Kolkata: Seagull Books, 2014.

GUHA, RANAJIT. (1983). Elementary Aspects of Peasant Insurgency in Colonial India. Delhi: Oxford University Press.

JAMESON, FREDRIC (1981). The Political Unconscious: Narrative as a Socially Symbolic Act. London and New York: Routledge, 2002.

MILL, JAMES (1824). An Essay on Government. Cambridge: Cambridge University Press, 1937.

MORETTI, FRANCO. (2013). The Bourgeois: Between History and Literature. London and New York: Verso.

MUKHERJEE, NEEL. (2008). Past Continuous / A Life Apart. London: Corsair, 2010.

MUKHERJEE, NEEL. (2014). The Lives of Others. London: Chatto\&Windus.

RAY, RABINDRA. (1988). The Naxalites and Their Ideology. Delhi: Oxford University Press, 2002. DOI: https://doi.org/10.1093/acprof:oso/9780198077381.001.0001

ROY, ASISH KUMAR. (1975). The Spring Thunder and After: A Survey of the Maoist and UltraLeftist Movements in India: 1962-1975. Calcutta: Minerva Associates.

SAMPIETRO, LUIGI. (2016). "Ridere per disperazione a Calcutta", Il Sole 24 Ore, 11th November 2016. 
$<$ https://www.ilsole24ore.com/art/cultura/2016-11-11/ridere-disperazione-calcutta$\underline{163307 . s h t m l \text { uuid }=\mathrm{ADzq} 7 \mathrm{oqB}}>$ Accessed 31/10/2018

SINGH, PRITAM. (2016). "The origins, influence, suppression, and resilience of the Maoist /Naxalite movement in India: 1967- Present”, Socialist History, 50: 85-104

SPIVAK, GAYATRI. (1988). "Can the Subaltern Speak?”. In: Patricia Williams and Laura Chrisman (eds), Colonial Discourse and Post-Colonial Theory: A Reader, 66-104. New York: Columbia University Press, 1994.

CARlotTa MARIA BeretTa is completing her PhD in Literary and Cultural Studies at Università di Bologna (Italy), where she is working on the representation of Calcutta in the fiction of Amitav Ghosh, Amit Chaudhuri, and Neel Mukherjee. Her research interests include postcolonial literatures, especially from the Indian Subcontinent, cultural studies, world literature, and geocriticism. 